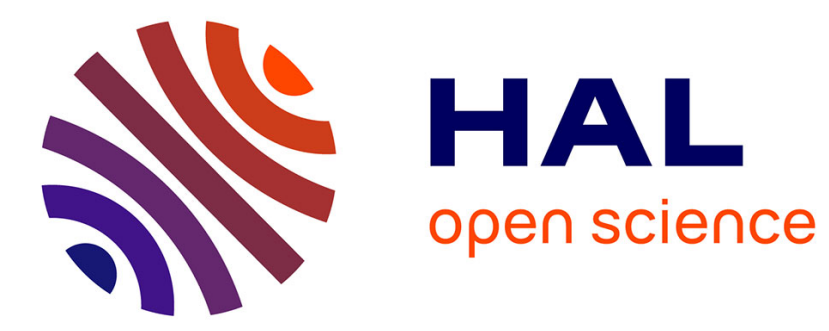

\title{
XAFS Characterization of Platinum Clusters Synthesized in the Channel of a Mesoporous Zeolite
}

\author{
T. Shido, T. Yamamoto, M. Harada, M. Ichikawa
}

\section{To cite this version:}

T. Shido, T. Yamamoto, M. Harada, M. Ichikawa. XAFS Characterization of Platinum Clusters Synthesized in the Channel of a Mesoporous Zeolite. Journal de Physique IV Proceedings, 1997, 7

(C2), pp.C2-855-C2-857. 10.1051/jp4:1997258 . jpa-00255341

\section{HAL Id: jpa-00255341 https://hal.science/jpa-00255341}

Submitted on 1 Jan 1997

HAL is a multi-disciplinary open access archive for the deposit and dissemination of scientific research documents, whether they are published or not. The documents may come from teaching and research institutions in France or abroad, or from public or private research centers.
L'archive ouverte pluridisciplinaire HAL, est destinée au dépôt et à la diffusion de documents scientifiques de niveau recherche, publiés ou non, émanant des établissements d'enseignement et de recherche français ou étrangers, des laboratoires publics ou privés. 


\title{
XAFS Characterization of Platinum Clusters Synthesized in the Channel of a Mesoporous Zeolite
}

\author{
T. Shido, T. Yamamoto, M. Harada and M. Ichikawa \\ Catalysis Research Center, Hokkaido University, Sapporo 060, Japan
}

\begin{abstract}
Pt}_{15}(\mathrm{CO})_{30}\right]^{2-}$ was synthesized by reductive carbonylation of $\mathrm{H}_{2} \mathrm{PtCl}_{6}$ in the channels of FSM-16 modified with $\mathrm{NEt}_{4} \mathrm{Cl}$. The platinum clusters in the channels whose diameter was $28 \AA$ were characterized by $\mathrm{Pt} \mathrm{L}_{\mathrm{II}}$ edge EXAFS as well as FT-IR, UV-vis spectroscopy, and TEM measurements. After exposure of $\mathrm{H}_{2} \mathrm{PtCl}_{6} / \mathrm{NEt}_{4} \mathrm{Cl} / \mathrm{FSM}-16$ to $\mathrm{CO}+\mathrm{H}_{2} \mathrm{O}$ at $323 \mathrm{~K}$, Pt carbonyl clusters were selectively produced. The $P t L_{\text {III }}$ edge EXAFS spectrum of this sample was exactiy the same as that of $\left[\mathrm{NEt}_{4}\right]_{2}\left[\mathrm{Pt}_{15}(\mathrm{CO})_{30}\right]$, and gave Pt-Pt distances typical of these types of platinum clusters at 2.68 and $3.08 \AA$. Uniform platinum "particles" (15 $\AA$ diameter) were observed in the channels of FSM-16 by a TEM measurement; this suggests that $\left[\mathrm{Pt}_{15}(\mathrm{CO})_{30}\right]^{2-}$ was synthesized in the channel of FSM-16. The platinum clusters in the channel were converted to platinum metal particles by evacuation above $363 \mathrm{~K}$. Pt $\mathrm{L}_{\mathrm{III}}$ EXAFS spectra of these samples revealed that the bridge $\mathrm{CO}$ of the clusters were desorbed by the evacuation at $343 \mathrm{~K}$ while retaining their cluster framework; the clusters were converted to $\mathrm{Pt}_{50.60}$ particles by evacuation above $363 \mathrm{~K}$.
\end{abstract}

\section{Introduction}

Synthesis of metal clusters clearly characterized at the molecular level in the channel or cage of zeolite, so called "ship-in-bottle synthesis" has great advantages for rational-preparation of the catalytic active site. Using this method, the structure of, the surroundings of the active site as well as the active site structure can be defined because zeolite is well-defined porous crystal [1].

Meso porous materials such as MCM-41[2,3] and FSM-16 [4,5] have been recently synthesized. These mesoporous materials have ordered channels with an uniform diameter. The size of the channels can be changed from 20 to $100 \AA$ by using different alkyl-trymethyl-anmonium as template. Since the size of the channels of MCM-16 and FSM-16 was much larger than that of conventional zeolites such as ZSM-5, AlPO-5, and NaY, they are potential hosts for inclusion of bulky organic and inorganic species. This allowed us to use new applications for the design of tailored metal catalysts accessible to larger substrates.

Chini type Pt clusters are composed of " $\mathrm{Pt}_{3}(\mathrm{CO})_{6}$ " units; the units were stacked to form $\left[\mathrm{Pt}_{3}(\mathrm{CO})_{6}\right]_{n}{ }^{2-}$ clusters $[6]$. The cross section of the $\mathrm{Pt}_{3}(\mathrm{CO})_{6}$ unit is about $8 \AA$ in diameter, and the inter trigoanl distance in the cluster is about $3 \AA$. In the super cage of $\mathrm{NaY},\left[\mathrm{Pt}_{3}(\mathrm{CO})_{6}\right]_{3}{ }^{2-}$ and $\left[\mathrm{Pt}_{3}(\mathrm{CO})_{6}\right]_{4}{ }^{2-}$ were abailable to be produced [7-10], while because of the size limitation of the supercage $(13 \AA),\left[\mathrm{Pt}_{3}(\mathrm{CO})_{6}\right]_{n}{ }^{2-}(\mathrm{n}>4)$ was not produced in the $\mathrm{NaY}$ supercage.

The goal of this paper is to characterize the Pt clusters synthesized in the channel of FSM-16 using EXAFS spectroscopy as well as IR and UV spectroscopy and TEM measurement. Further, structure transformation of the cluster was investigated.

\section{Experimental}

FSM-16 was synthesized as described in the literature [4]. FSM-16 was impregnated with $\mathrm{NEt} \mathrm{Cl}_{4} \mathrm{Cl}$ in aqueous solution to provide counter cations of $\mathrm{Pt}$ clusters. The NEt 4 Cl modified FSM-16 was impregnated with $\mathrm{H}_{2} \mathrm{PtCl}_{6}$ in aqueous solution. The loading of $\mathrm{NEt}_{4} \mathrm{Cl}$ and $\mathrm{Pt}$ atoms were $1.37 * 10^{-4} \mathrm{~mol} / \mathrm{gcat}$ and $5 \mathrm{wt} \%$ respectively. The sample was exposed to a mixture of $\mathrm{CO}(26.7 \mathrm{kPa})$ and $\mathrm{H}_{2} \mathrm{O}(2.7 \mathrm{kPa})$ at $323 \mathrm{~K}$ to produce $\mathrm{Pt}$ carbonyl clusters.

Pt-LIII edge EXAFS (extended X-ray absorption fine structure) spectra were measured at BL-10B at the Photon Factory of the National Institute for High Energy Physics (Tsukuba, Japan). The energy and current of electrons in the storage ring were $2.5 \mathrm{GeV}$ and $250-365 \mathrm{~mA}$ respectively. A Si(311) channel cut monochromator was used. X-ray was detected in ion chambers filled with a mixture of $\mathrm{Ar}$ and $\mathrm{N}_{2}$ gases. The spectra were measured at room temperature in the transmission mode.

The EXAFS spectra were analyzed by a computer program supplied by Technos Co. LTD [11]. The background was subtracted using the McMaster function, and the baseline was estimated using the cubic sprain method. The $k^{3}$ weighted EXAFS function was Fourier transformed into R-space and inverse Fourier transformed into k-space. The $k$ and $R$ ranges were $3.5-18 \AA^{-1}$ and 1.09-3.31 $\AA$ respectively. The Fourier filtered EXAFS functions were fitted according to calculated EXAFS functions. Backscattering amplitude and phase shift functions of $\mathrm{Pt}-\mathrm{Pt}, \mathrm{Pt}-\mathrm{C}$ and $\mathrm{Pt}-\mathrm{O}$ (of $\mathrm{Pt}-\mathrm{CO}$ ) used in this analysis were obtained 
experimentally from $\mathrm{Pt}$ foil $(\mathrm{Pt}-\mathrm{Pt})$ and $\mathrm{W}(\mathrm{CO})_{6}(\mathrm{Pl}-\mathrm{C}$ and $\mathrm{Pt}-\mathrm{O})$ respectively.

\section{Results and discussion}

\subsection{Formation of $\mathrm{Pt}$ clusters in FSM-16}

Figure 1 shows Fourier transformed $P t L_{\text {III }}$ EXAFS functions of $\mathrm{Pt}$ clusters synthesized in $\mathrm{NEt}_{4} \mathrm{Cl} / \mathrm{FSM}-16, \mathrm{Pt}_{12}(\mathrm{CO})_{24} / \mathrm{NaY}$, and $\left[\mathrm{NEt}_{4}\right]_{2}\left[\mathrm{Pt}_{15}(\mathrm{CO})_{30}\right]$. The EXAFS function of the $\mathrm{Pt}$ clusters in NEt ${ }_{4} \mathrm{Cl} / \mathrm{FSM}-16$ is similar to that of $\left[\mathrm{Net}_{4}\right]_{2}\left[\mathrm{Pt}_{3}(\mathrm{CO})_{6}\right]_{5}{ }^{2-}$. These spectra were inverse Fourier transformed and fitted to five shells, two $\mathrm{Pt}-\mathrm{Pt}$, two $\mathrm{Pt}-\mathrm{C}$, and one $\mathrm{Pt}-\mathrm{O}$ contribution. Table 1 shows coordination number $(\mathrm{CN})$, inter-atomic distance $(\mathrm{R})$, correction of threshold energy $\left(\Delta \mathrm{E}_{0}\right)$, and the difference of the Debye-Waller factor from reference compounds $\left(\Delta \sigma^{2}\right)$. The structural parameters of the $\mathrm{Pt}$ cluster in $\mathrm{NEt}_{4} \mathrm{Cl} / \mathrm{FSM}-16$ agree with those of $\left[\mathrm{NEt}_{4}\right]_{2}\left[\mathrm{Pt}_{3}(\mathrm{CO})_{6}\right]_{5}$ in the error bar. The results of the EXAFS confirmed that the $\left[\mathrm{Pt}_{3}(\mathrm{CO})_{6}\right]_{n}{ }^{2-}$ cluster was produced in the channel of FSM-16. In the case of $\mathrm{Pt}_{12}(\mathrm{CO})_{24} / \mathrm{NaY}$, the Pt-Pt distance of inter $\mathrm{Pt}_{3}$ triangles was shorter than that of the reference compound and $\mathrm{Pt}_{15} / \mathrm{FSM}-16$. This may be caused by the effect of the zeolite wall on $\mathrm{NaY}$. Since the size of the supercages of $\mathrm{NaY}$ is $13 \AA$ in diameter, the Pt clusters in NaY may be distorted. In contrast, since the channel of FSM-16 is large enough (30 $\dot{A}$ in diameter ), the Pt clusters in the channel were not distorted. No contribution of $\mathrm{Pt}-\mathrm{Cl}$ was observed, which means that most $\mathrm{H}_{2} \mathrm{PtCl}_{6}$ was converted to $\left[\mathrm{Pt}_{3}(\mathrm{CO})_{6}\right]_{n}{ }^{2-}$ clusters. IR and $\mathrm{UV}$-vis spectra of the Pt clusters synthesized in $\mathrm{NEt}_{4} \mathrm{Cl} / \mathrm{FSM}-16$ suggested that $\left[\mathrm{Pt}_{3}(\mathrm{CO})_{6}\right]_{5}{ }^{2-}$ was synthesized by reductive carbonylation of $\mathrm{H}_{2} \mathrm{PtCl}_{6} / \mathrm{NEt}_{4} \mathrm{Cl} / \mathrm{FSM}-16$. In the TEM photo-graph, small $\mathrm{Pt}$ clasters $15 \AA$ in diameter were observed; large crystals were not observed, which clearly showed that the Pt clusters were dispersed in the channel of FSM-16.

\subsection{Formation of small $P t$ particles from the $P t$} clusters in $\mathrm{NEt}_{4} / \mathrm{FSM}-16$

Figure 2 shows Fourier transformed EXAFS functions of $\mathrm{Pt}$ clusters $\left(\left[\mathrm{Pt}_{3}(\mathrm{CO})_{6}\right]_{5}{ }^{2-}\right)$ in $\mathrm{NEt}_{4} \mathrm{Cl} / \mathrm{FSM}-16$ evacuated at 300,343 , 363,393 , and $473 \mathrm{~K}$ respectively. No phase shift correction was carried out in Fig.2. By the evacuation at $343 \mathrm{~K}$, the peak at 2.75 $\AA$ decreased, and the peak at $2.4 \AA$ shifted to $2.6 \AA$ when the sample was evacuated at $363 \mathrm{~K}$.

Table 2 shows structural parameters derived by EXAFS analysis. When the sample was evacuated at $343 \mathrm{~K}, \mathrm{CN}$ of Pt-C (bridge) decreased from 2.1 to 1.1. In contrast, other parameters such as distance and co-ordination number of two Pt-Pt contributions, $\mathrm{Pt}-\mathrm{C}($ terminal) and $\mathrm{Pt}-\mathrm{O}$ bridge remain unchanged. These results suggest that bridge $\mathrm{CO}$ was desorbed by evacuation at $343 \mathrm{~K}$ and the cluster framework remain unchanged. The $\mathrm{CN}$ of $\mathrm{Pt}$ $O$ remains unchanged while $\mathrm{CN}$ of $\mathrm{Pt}-\mathrm{C}(\mathrm{b})$ decreased. This suggests that the contribution of Pt-O mainly comes from $\mathrm{Pt}-\mathrm{O}$ of the terminal $\mathrm{CO}$.

When the sample was evacuated at $363 \mathrm{~K}$, Pt-Pt distance changed. Pt-Pt distances characteristic to $\left[\mathrm{Pt}_{3}(\mathrm{CO})_{6}\right]_{n}{ }^{2-}$ disappeared and a Pt-Pt distance of metal Pt particles was observed at $2.73 \AA$ with $\mathrm{CN}$ of 7.3. The $\mathrm{CN}$ of 7.3 suggests that particle size was $\mathrm{Pt}_{50-60}$ with a diameter of $15 \AA$. Pt-C and $\mathrm{Pt}-\mathrm{O}$ contributions were also observed at 1.87 and $3.07 \AA$. The $\mathrm{CN}$ of Pt-C was 0.4 and suggests that all surface $P t$ atoms were coordinated by adsorbed

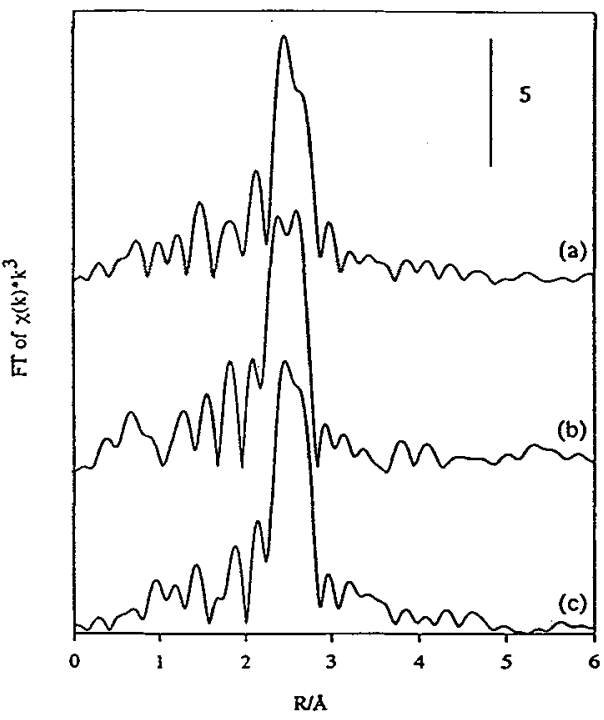

Figure 1. Fourier Transformed $\mathrm{k}^{3}$ weighed EXAFS function of (a) $\left[\mathrm{NEt}_{4}\right]_{2}\left[\mathrm{Pt}_{3}(\mathrm{CO})_{6}\right]_{5}^{2-/ B N}$ (BN=Boron nitride), (b) $\left[\mathrm{Pt}_{3}(\mathrm{CO})_{6}\right]_{4}{ }^{2-} / \mathrm{NaY}$, and (c) Pt clusters in $\mathrm{NEt}_{4} \mathrm{Cl} / \mathrm{FSM}$ - 16 .

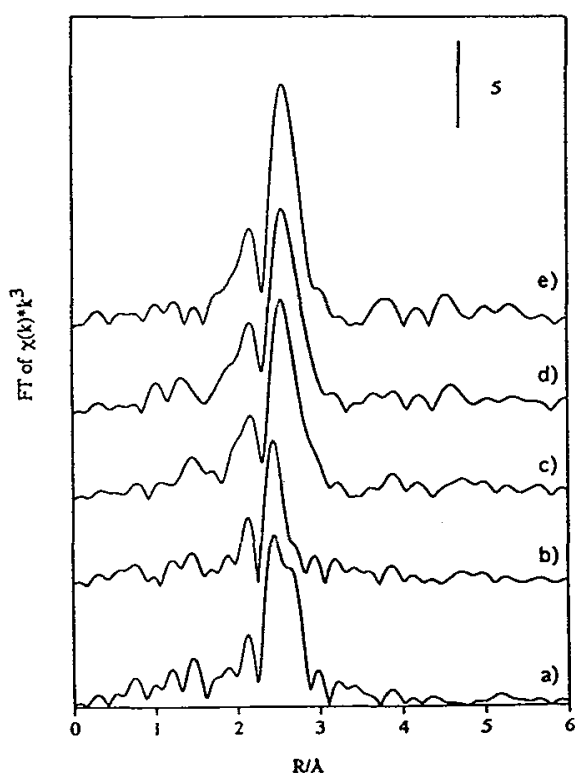

Figure 2. Fourier transformed $k^{3}$ weighted EXAFS function of $\mathrm{Pt}$ clusters in $\mathrm{NEt}_{4} \mathrm{Cl} / \mathrm{FSM}-16$ evacuated at a) $300 \mathrm{~K}$, b) $343 \mathrm{~K}$, c) $363 \mathrm{~K}$, d) $393 \mathrm{~K}$ and c) $473 \mathrm{~K}$. 
$\mathrm{CO}$, because the proportion of surface $\mathrm{Pt}$ atoms was estimated to be 0.45 from the $\mathrm{CN}$ of Pt-Pt. The $\mathrm{CN}$ of adsorbed $\mathrm{CO}$ on the $\mathrm{Pt}$ particles decreased as the evacuation temperature increased; adsorbed $\mathrm{CO}$ was disappeared at 473 $\mathrm{K}$.

IR spectra of the Pt clusters in FSM-16 evacuated at various temperatures agree with EXAFS data. When the sample was evacuated at $343 \mathrm{~K}$, bridge $\mathrm{CO}$ at $1871 \mathrm{~cm}^{-1}$ disappeared. Terminal $\mathrm{CO}$ adsorbed on $\mathrm{Pt}_{50-60}$ cluster began to desorb at $373 \mathrm{~K}$ and disappeared at $473 \mathrm{~K}$. The TEM photograph showed that $\mathrm{Pt}_{50-60}$ clusters were dispersed homogeneously in the channel of FSM-16. No large Pt particles were observed in the TEM photograph.

From EXAFS, IR, and TEM results, we propose a scheme of the formation and transformation of $\left[\mathrm{Pt}_{3}(\mathrm{CO})_{6}\right]_{5}{ }^{2-}$ in $\mathrm{NEt}_{4} \mathrm{Cl} / \mathrm{FSM}-16$ as shown in scheme 1 . $\left[\mathrm{Pt}_{3}(\mathrm{CO})_{6}\right] 5^{2-}$ clusters were produced by the reductive carbonylation of $\mathrm{H}_{2} \mathrm{PtCl}_{6}$. By the evacuation at $343 \mathrm{~K}$, the bridge $\mathrm{CO}$ of the $\left[\mathrm{Pt}_{3}(\mathrm{CO})_{6}\right]_{5}^{2-}$ in the channel of FSM-16 was desorbed, while the cluster framework remained. By the evacuation at $363 \mathrm{~K}$, the $\left[\mathrm{Pt}_{3}(\mathrm{CO})_{6}\right] s^{2-}$ clusters were converted to $\mathrm{Pt}_{\text {50-60 }}$ particles whose surface $\mathrm{Pt}$ atoms were saturated by adsorbed $\mathrm{CO}$. The adsorbed $\mathrm{CO}$ on the Pt particles were desorbed by the evacuation at $473 \mathrm{~K}$. TEM results clearly show that the Pt particle exists in the channel of FSM-16 and that the size of the Pt particle was homogeneous.

\section{Conclusions}

1) $\left[\mathrm{Pt}_{3}(\mathrm{CO})_{6}\right] 5^{2-}$ is produced in the channel of FSM- 16 by the reductive carbonylation of $\mathrm{H}_{2} \mathrm{PtCl}_{6}$ impregnated in FSM-16 which was modified with $\mathrm{NEt}_{4} \mathrm{Cl}$.

2) The bridge $\mathrm{CO}$ of $\left[\mathrm{Pt}_{3}(\mathrm{CO})_{6}\right]_{5}{ }^{2-}$ in the FSM-16 channel was selectively removed by evacuation at $343 \mathrm{~K}$, and the clusters were converted to $\mathrm{Pt}_{50-60}$ particles by evacuation above $363 \mathrm{~K}$. Resulting Pt particle of ca. $15 \AA$ size was formed uniformely inside the ondered mesoporous channels of $28 \AA$ diamter.

\section{References}

[1] M.Ichikawa, Adv. Catal. 38, 283 (1992).

[2] C.T.Kresge, M.E.Leonowicz, W.J.Roth, J.C.Vartuli, J.S.Beck, Nature, 359, 710 (1992).

[3] J.S.Beck, J.C.Vartuli,W.J.Roth, M.E.Leonowicz, C.T.Kresge, K.D.Schmitt, C.T-W.Chu, D.H.Olson, E.W.Sheppard, S.B. McCutlen, J.B.Higgins, J.L.Schlenker, J. Am. Chem. Soc. 114. 10834 (1992).

[4] S.Inagaki, Y.Fukushima, K.Kuroda, J. Chem. Soc., Chem. Commun 680 (1993).

[5] S.Inagaki, Y.Fukushima, K.Kuroda, Stud. Surf. Sci. Catal. $.84,125$ (1994).

[6] J.C.Calabrese, L.F.Dahl, P.Chini, G.Longoni, S.Martinengo, J.Am.Chem. Soc. 96, 2614 (1974).

17) A.De Mallmann, D.Barhomeuf, Catal. Lelt., 5293 (1990).

[8] G.-J.,Li, T.Fujimoto, A.Fukuoka, M.Ichikawa, J. Chem. Soc., Chem. Commun, 1337 (1991).

[9] G.-J.,Li, T.Fujimoto, A.Fukuoka, M.Ichikawa, Catal, Lett. 12, 171 (1992)

[10] G.S.-Ekloff, R.J.Lipski, N.l.Jaeger, P.Hulstede, Catal. Lett. 30, 65 (1995).

[11] user manual of Technos EXAFS analyzing program
Table 1. Structural parameters of Pt carbonyl clusters derived from $P t L_{\text {III }}$ EXAFS.

\begin{tabular}{|c|c|c|c|c|c|}
\hline Compound/shell & $\mathrm{CN}$ & $\mathrm{R} / \mathrm{A}$ & $\Delta \mathrm{E}_{0} / \mathrm{eV}$ & $\Delta \sigma^{2} / 10^{3} A^{2}$ & Residual(\%) \\
\hline \multicolumn{6}{|l|}{$\left[\mathrm{NEt}_{4}\right]_{2}\left[\mathrm{Pt}_{13}(\mathrm{CO})_{30}\right]$} \\
\hline Pt.Pt & 2.1 & 2.68 & 6.5 & -1.8 & \multirow{5}{*}{7.5} \\
\hline Pr-Pt & 1.5 & 3.07 & -8.5 & 5.8 & \\
\hline Pt-C(b) & 1.5 & 2.10 & 0.4 & 2.0 & \\
\hline $\mathrm{Pt}-\mathrm{C}(\mathrm{t})$ & 1.0 & 1.89 & -5.9 & 1.3 & \\
\hline Pto & 1.0 & 2.99 & 4.6 & 4.5 & \\
\hline \multicolumn{6}{|l|}{$\left[\mathrm{Pt}_{12}(\mathrm{CO})_{24}\right] / \mathrm{NaY}$} \\
\hline $\mathbf{P t}-\mathbf{P t}$ & 2.2 & 2.67 & 6.5 & -1.6 & \multirow{5}{*}{12.2} \\
\hline $\mathrm{Pt}-\mathrm{Pt}$ & 1.4 & 2.99 & -8.5 & 7.4 & \\
\hline Pt-C(b) & 1.6 & 2.14 & 0.4 & 2.0 & \\
\hline$P t-C(t)$ & 0.9 & 3.99 & -5.8 & 0.9 & \\
\hline Pto & 1.0 & 2.99 & -4.6 & 1.3 & \\
\hline \multicolumn{6}{|c|}{$\left[\mathrm{Pr}_{15}(\mathrm{CO})_{30}\right] \mathrm{NEt} / \mathrm{FSM}-16$} \\
\hline Pt-Pt & 2.3 & 2.68 & 3.7 & -0.7 & \multirow{5}{*}{9.6} \\
\hline Pt-Pt & 1.7 & 3.08 & -6.4 & 7.0 & \\
\hline Ptoc(b) & 2.2 & 2.08 & -7.6 & 5.8 & \\
\hline$P t-C(t)$ & 1.3 & 1.90 & -10.0 & 2.6 & \\
\hline $\mathrm{Pt}-\mathrm{O}$ & 1.0 & 3.01 & -2.3 & 3.0 & \\
\hline
\end{tabular}

Table 2. Structural parameters of $\mathrm{Pt}$ clusters $\left(\left[\mathrm{Pt}_{3}(\mathrm{CO})_{6}\right]_{5}{ }^{2-}\right)$ in $\mathrm{NEt}_{4} \mathrm{Cl} / \mathrm{FSM}-16$ evacuated at various temperatures.

\begin{tabular}{ccccccc}
\hline evac. temp. /shell & CN & RA & $\Delta E_{0} / e V$ & $\Delta \sigma^{2} / 10^{-3} \mathrm{~A}^{2}$ & Residual(\%) \\
\hline evac. at 300 K & & & & & \\
Pt-Pt & 2.3 & 2.68 & 3.0 & -0.8 & \\
Pt-Pt & 1.7 & 3.10 & -2.1 & 5.6 & \\
Pt-C(b) & 2.1 & 2.10 & 3.8 & 6.2 & 11.8 \\
Pt-C(t) & 1.3 & 1.90 & -9.9 & 2.6 & \\
Pt-O & 1.0 & 3.03 & -0.8 & 2.8 & \\
\hline evac. at 343 K & & & & & \\
Pt-Pt & 2.2 & 2.69 & -2.5 & 0.4 & \\
Pt-Pt & 1.4 & 3.10 & -7.5 & 6.0 & \\
Pt-C(b) & 1.6 & 2.13 & -1.6 & 6.4 & \\
Pt-C(t) & 0.9 & 1.91 & -8.9 & 5.8 & \\
Pt-O & 1.0 & 3.02 & -1.3 & 4.5 & \\
evac. at 363 K & & & & & \\
Pt-Pt & 7.3 & 2.73 & -2.9 & 3.5 & \\
Pt-C & 0.4 & 1.87 & -7.8 & -2.8 & \\
Pt-O & 0.3 & 3.07 & 4.5 & 2.2 & \\
evac. at 393 K & & & & & \\
Pt-Pt & 8.3 & 2.73 & -2.9 & 3.5 & \\
Pt-C & 0.3 & 1.88 & -7.8 & -2.8 & \\
Pt-O & 0.3 & 3.07 & 4.5 & 2.2 & \\
\hline evac. at 473 K & & & & & \\
Pt-Pt & 7.8 & 2.72 & -3.2 & 2.7 & \\
\hline
\end{tabular}

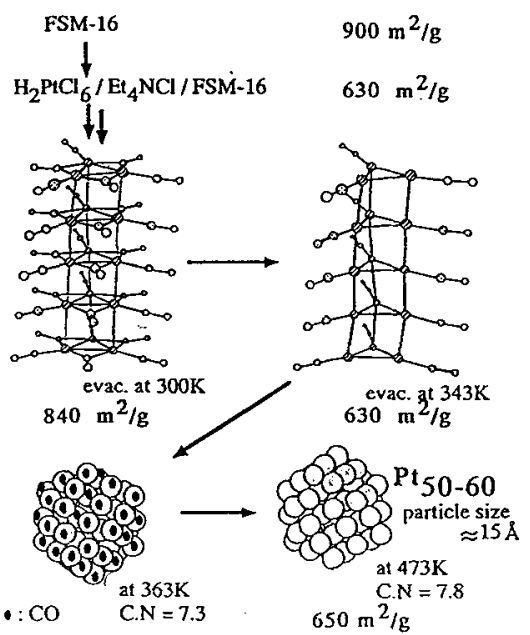

Scheme 1 Structure transformation of Pt clusters $\left(\left[\mathrm{Pt}_{3}(\mathrm{CO})_{6}\right]_{5}^{2-}\right)$ in $\mathrm{NEt}_{4} \mathrm{Cl} / \mathrm{FSM}-16$ 